\title{
Hydrozoan diversity on hard bottom in Kongsfjorden, Svalbard
}

\author{
ANDREY VORONKOV ${ }^{1,2}$, SOFIA D. STEPANJANTS ${ }^{1}$ AND HAAKON HOP \\ ${ }^{1}$ Laboratory of Marine Research, Zoological Institute of the Russian Academy of Sciences, Universitetskaja emb., 1199034 St \\ Petersburg, Russia, ${ }^{2}$ Institute for Arctic and Marine Biology, University of Troms $\varnothing$, N-9037 Troms $ø$, Norway, ${ }^{3}$ Norwegian Polar \\ Institute, N-9296 Tromsø, Norway
}

\begin{abstract}
Hydroids in Kongsfjorden, Svalbard, were studied on five hard-bottom transects along gradients of environmental conditions from the glacier at the fjord's head to the fjord's mouth at depth-range o-3o m. Hydrozoa colonies are widely distributed on rock and gravel substrata in Kongsfjorden. In general, however, hydroids are not dominant or subdominant in zoobenthic communities. The exception is Symplectoscyphus tricuspidatus var. acuminatus, colonies of which were sometimes abundant enough to determine the community structure and characteristics of benthic diversity. Of the 23 species recorded in this study, Laomedea flexuosa, Phialella quadrata and Halecium tenellum as well as representatives of family Stylasteridae were recorded from Svalbard waters for the first time. Hydroid diversity was highest in the zoobenthic community structured by branched bryozoans. The abundance and distribution of hydroids were reduced, to some extent, in the inner part of the fjord compared to the outer fjord. Species richness of hydroids was high at shallow depths, decreased at around $15 \mathrm{~m}$ and then increased again to $30 \mathrm{~m}$ depth. Species with Low-boreal-Arctic and Panoceanic distributional ranges were the most frequently occurring species. Depth, type of background substratum and amount of silt on its surface were the main factors influencing hydroid distribution. Description of all recorded taxa distributions together with data on their habitat and associations in zoobenthic communities are presented in an Appendix.
\end{abstract}

Keywords: Hydrozoa, Kongsfjorden, Svalbard, benthic diversity, hard substrata, zoobenthic communities, environmental gradients

Submitted 5 May 2009; accepted 16 November 2009

\section{INTRDDUCTION}

Hydroids (Hydrozoa) are common worldwide in almost all types of benthic communities. The North Atlantic is no exception, and hydroids constitute a considerable portion of total benthic biodiversity. According to recent faunistic summaries, 134 species of Hydrozoa, comprise about $4.7 \%$ of the total number of zoobenthic species found in the Barents Sea (Stepanjants, 2001). Together with Polychaeta (347 species), Amphipoda Gammaridea (337 species), Mollusca Gastropoda (258 species) and Bryozoa (273 species), hydroids are among the five most diverse macrozoobenthic taxa recorded in the Barents Sea region. Data for the Norwegian Sea (approximately 90 species in Oslofjorden according to Bonnevie (1898, 1899) and Christiansen (1972)) and Greenland and Iceland (157 species in Schuchert (2001)) confirm the conclusion that hydroids are highly diverse and broadly distributed in the north-east Atlantic.

The Svalbard archipelago is a region where both Arctic and temperate conditions influence the ecosystem. This region is of special interest for many taxonomic and ecological benthic studies because it contains a high number of species with different distributional ranges. Norwegian, Russian, Swedish and Danish 19th Century scientific expeditions constitute the basis for detailed studies of different taxonomic groups, including hydroids (e.g. Birula, 1897, 1900;

\section{Corresponding author:}

A. Voronkov

Email: Andrey.Voronkov@npolar.no
Bonnevie, 1899), from Svalbard. Studies of e.g. Jäderholm (1908, 1909, 1916), Rylov (1923) and Kramp (1932, 1942) allowed Palerud et al. (2004) to expand the Broch (1910) list of 60 hydroid species in Svalbard waters to 106 species. The Hydrozoa faunal composition of Svalbard was recently updated by Ronowicz (2007).

Kongsfjorden, on the west coast of Spitsbergen, the largest island in the Svalbard archipelago, is considered a European Reference Site for studies of marine biodiversity (Warwick et al., 2003). Surveys on some taxa from Kongsfjorden are published (Bryozoa: Gontar et al. (2001), Kuklinski (2002); Mollusca: Wlodarska-Kowalczuk (2007); Sipuncula: Kedra \& Murina (2007); Crustacea: Lagardere (1968), Blazewicz-Paszkowycz \& Sekulska-Nalewajko (2004); Porifera: Assmann (2004)), but the majority of benthic taxonomic groups still needs better description. The present study focuses on the composition of Hydrozoa on hard substrata in Kongsfjorden.

Despite extensive research on Arctic hydroids, there is still a lack of detailed information on the depth distribution of hydroids. Earlier studies in the Arctic revealed maximum hydroid species richness between 50 and $100 \mathrm{~m}$ depth (Stepanjants, 1989), but this pattern has been re-examined (Schuchert, 2000). Our lack of knowledge of hydroid distribution is partly the result of very limited information about spatial distribution of hydroids in coastal areas, especially in the upper sublittoral $(0-30 \mathrm{~m})$. This depth-range was surveyed by SCUBA divers in the present study.

The majority of hydrozoan species have a complex life cycle with colonial benthic stage (sessile polyps) and adult pelagic 
stage (free living medusae). The benthic stage of the hydroids life cycle is associated, as a rule, with hard background substrata, rock or stones. They are rarely associated with sandy, and even more rarely with silty substrata. The majority of hydroid polyps are also common epibionts. They attach to algae, other hydroids, shells of molluscs, carapaces of crustaceans, etc. The role of hydroids, however, in different benthic assemblages in northern latitudes is still poorly understood.

Our lack of knowledge of hydroids stems, in part, from the fact that in ecological studies of the entire benthic community there is usually limited emphasis on species inventory. In the case of Hydrozoa, one of the main reasons they are not accurately represented in ecological studies is that they are difficult to sample and identify; the majority of hydroids are delicate and require the use of special sampling and preservation methods to obtain identifiable samples. Accordingly, hydroids in ecological studies most often are identified at taxonomic levels above species (e.g. for Kongsfjorden: Hansen \& Haugen (1989), Jørgensen \& Gulliksen (2001), Sahade et al. (2004)) or ignored (Kaczmarek et al. (2005), Carlsen et al. (2007)), although there are exceptions (Lippert et al., 2001).

At the same time, taxonomists are usually not interested in the role of hydroids in the structure and function of communities. For hydroids (that are mainly colonial organisms), the quantification of characteristics such as biomass is especially important in order to estimate their role in benthic communities.

The main purpose of our study is to present an integrated description of hydroids on hard substrata in Kongsfjorden that combines data on the species composition with the description of the role of each of the species in the community.

\section{MATERIALS AND METHODS}

Kongsfjorden is located on the north-western part of Spitsbergen (Svalbard archipelago) latitude $79^{\circ} \mathrm{N}$. It is a glacial fjord influenced by both Arctic and Atlantic water masses. The warm West Spitsbergen Current interacts with local environmental conditions to create ecologically important gradients in temperature, salinity, turbidity, and concentrations of organic and inorganic suspended and sedimented particulate matter (Hop et al., 2002; Svendsen et al., 2002).

Samples of benthos from hard substrata in Kongsfjorden were collected between August and September in 1996 and 1998. We sampled 5 transects distributed along the gradient of environmental conditions from the outermost part of the fjord close to the open sea to the innermost part of the fjord near tidal glaciers (Figure 1). Samples from transects 'Kapp Mitra' (MITR), 'Kapp Guissez' (GUIS), 'Hansneset' (HANS), 'Juttaholmen' (JUTT) and 'Ossian Sars' (OSSI) at the mountain base of Colletthøgda were generally collected from o to $30 \mathrm{~m}$ depth except for the inner part. The benthic flora and fauna on transects were collected by SCUBA divers within square frames $0.25 \mathrm{~m}^{2}$ from each of the depths $0-1.3-2.5-$ $5-10-15-20-25-30 \mathrm{~m}$. Two frames were taken from hard substrata at each of these depths. The sampling at transects JUTT and OSSI was limited to depths of $15 \mathrm{~m}$ and $5 \mathrm{~m}$,

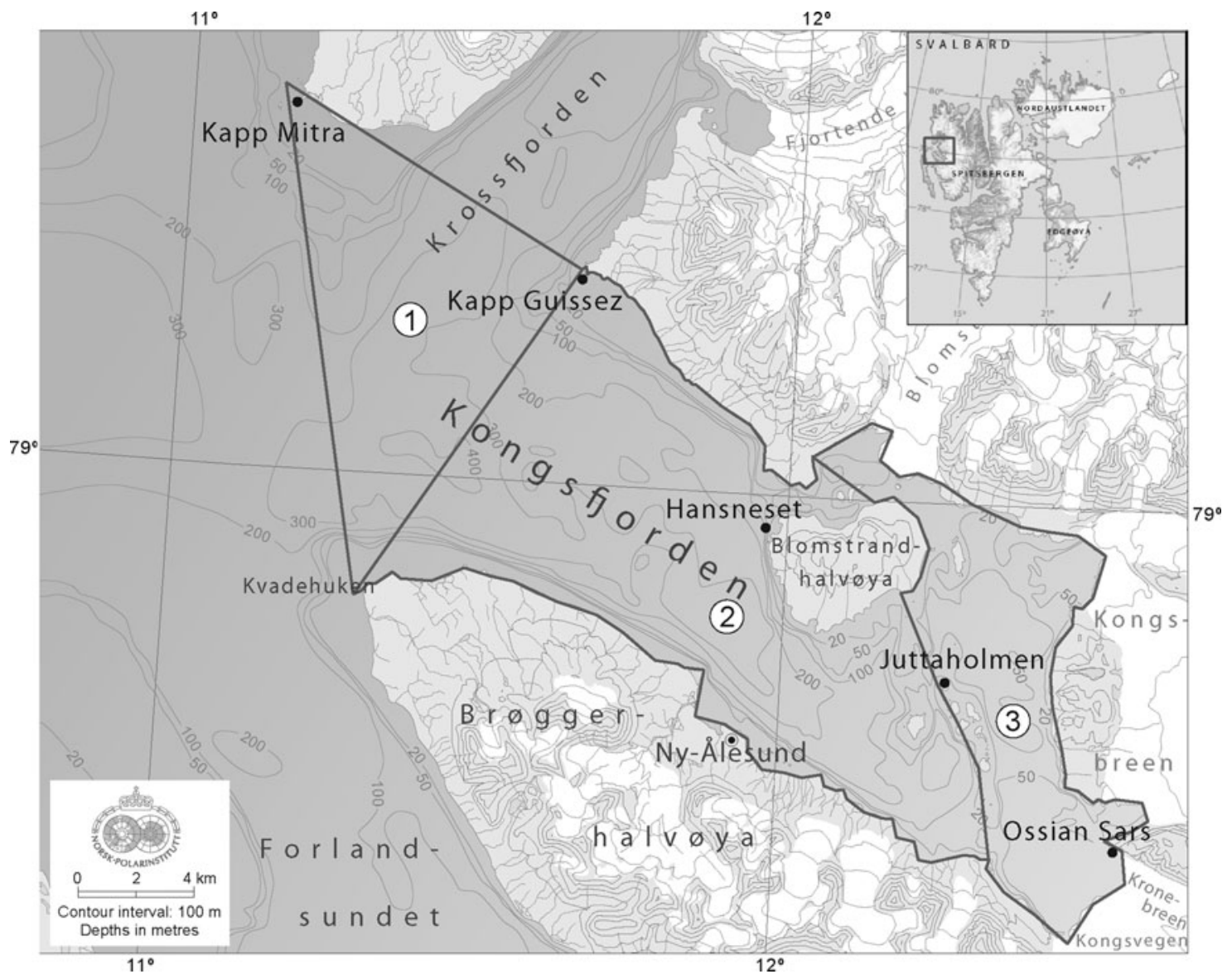

Fig. 1. Map of Kongsfjorden with location of the sample transects (black dots). Bold lines define the outer (1), middle (2) and inner (3) parts of the fjord (modified after Hop et al., 2002). 
respectively, because deeper hard substrata are covered by thick layer of silt at these sites. Samples from o m depth on transect MITR were not collected because the site is extremely exposed to wave impact. One additional sample from $1.3 \mathrm{~m}$ depth at HANS was collected. Thus, data on species composition, abundance and weight of benthic animals and algae were obtained from a total of 63 samples. The distinguishing features of each sample location, including the main features and composition of substratum, the amount of silt on substratum, the substratum angle and the current velocity were recorded at the time of sampling (Appendix 1).

All benthic organisms, including those strongly attached to the substratum were collected from the surface or detached from substratum with diver's knives and put into diver's sampling bags with a mesh size of $1 \mathrm{~mm}$. Small organisms and small substratum particles were collected from within frames using an underwater suction pump. Stones, empty shells, etc within the frame were also collected and examined for colonies of epibionts. After primary sorting, hydroid epibionts from substratum-forming organisms, such as barnacles, branched bryozoan colonies and algal rhizoids, were detached. For weight measurement, small hydroids were delicately detached from their substrata (shells, parts of algae rhizoids and bryozoans) using forceps and scissors when possible. In other cases, weight was approximated from known weight of colonies of similar size. In the hydroid species descriptions, we generally describe the type of background substratum for the whole benthic community, and sometimes the type of substratum to which hydroids were attached.

A list of identified taxa is given according to the classification of Stepanjants S.D. (http://www.zin.ru/ZOODIV/ animals.asp?id=1070219304130018).

Species richness was quantified as simply the number of species. Multidimensional scaling, ANOSIM, SIMPER and cluster analysis were conducted using the statistical package PRIMER (Version 5.2.9). Canoco for Windows (version 4.55) was used to conduct canonical correspondence analysis relating species presence and environmental variables.

\section{RESULTS AND DISCUSSION}

We collected at least 23 species of hydroids from 21 genera (Table 1). Some colonies from the genera Garveia, Halecium and from the family Stylasteridae are not identified to species level (see descriptions in Appendix 2). Three species we collected have not been previously recorded in Svalbard waters: Laomedea flexuosa Alder, 1857, Phialella quadrata (Forbes, 1848) and Halecium tenellum Hincks, 1861. Also, representatives of the family Stylasteridae have not been recorded for Svalbard waters. Only 6 species, Symplectoscyphus tricuspidatus (Alder, 1856), Campanularia volubilis (Linnaeus, 1758), Orthopyxis integra (MacGillivray, 1842), Calycella syringa (Linnaeus, 1767), Lafoea dumosa (Fleming, 1820) and Sertularella rugosa (Linnaeus, 1758), of the 23 species we collected have been found in Kongsfjorden. The species not recorded for Svalbard and Kongsfjorden are common in the Arctic, and their absence in the list of species for Svalbard (Palerud et al., 2004; Ronowicz, 2007) is apparently a consequence of insufficient sampling effort, not a singularity of recently studied habitats.
We did not collect Halecium curvicaule Lorenz, 1886, which has been found in Kongsfjorden earlier (Lippert et al., 2001). With $H$. curvicaule the list of hydroids of Kongsfjorden consists of 24 species. The list of hydroids of Svalbard waters is thus extended to 127 species (after Palerud et al., 2004; Ronowicz, 2007). Accordingly, hydroids comprise $8.1 \%$ of the total number of the bottom-associated macrofaunal species found in Svalbard waters. The curve of the cumulative hydroid species count (Clarke \& Warwick, 2001) is not asymptotic for 63 samples, so further sampling is expected to increase the number of hydroid species from Kongsfjorden.

Hydroids occurred in 43 of the 63 samples, and comprise $5.7 \%$ of total zoobenthic species richness on hard substrata in Kongsfjorden. This is a relatively high contribution to total species richness. Only bryozoans, polychaetes, amphipods and gastropods are more species-rich than hydroids. Hydroid species are, however, characterized by an uneven distribution by sampling localities. As a result, they represent only $2.9 \%$ of total species records (identifications) in samples (A. Voronkov, unpublished data).

The present analysis is based on results of 109 hydroid taxa identifications. Of the 23 species in our samples, 15 species (65.2\% of total hydroid species richness) belong to the order Leptothecata and 8 species to the order Anthoathecata (Table 1). The frequency of occurrence of Leptothecata species in samples is even greater, $83.8 \%$ of the total number of identifications. In 43 samples, we recorded Leptothecata 88 times as opposed to 17 occurrences for Anthoathecata (Table 1). Similar proportions for species richness are reported by Ronowicz et al. (2008) for Hornsund fjord samples from kelp habitats, at 5 to $10 \mathrm{~m}$ depth. There, Anthoathecata also represents a small proportion (14.3\%) of the total hydroid species richness.

The most frequently occurring species included: Orthopyxis integra (in 16 samples), Lafoea dumosa (in 16 samples) and Campanularia volubilis (in 14 samples). Less common were Filellum serpens (in 9 samples), Symplectoscyphus tricuspidatus var. acuminatus and Halecium labrosum (in 8 samples each) and Candelabrum phrygium (in 6 samples; Table 1). These 7 species represent $69.7 \%$ of the total number of hydroid identifications. Thirty-three records of the remaining 16 species (presented in 1-4 samples) represent $30.3 \%$ of the total number of identifications. Therefore, occurrence of hydroid species has a pattern of distribution different from normal statistical distribution. A relatively small number of widely distributed and abundant species is accompanied by a large number of 'rare' species. This is common for zoobenthos on hard substrata (e.g. Gulliksen et al., 1980) and hydroids are not an exception.

The six most commonly occurring species primarily account for the dissimilarity in species composition among samples from different transects, depths and community types (SIMPER analysis (Clarke \& Warwick, 2001)).

The number of hydroid species in samples varied from 1 to 9, with $90 \%$ of the samples containing 1 to 4 species. This resulted in a very high coefficient of variation, $70.45 \%$ (mean 2.63 species per sample, SD 1.85), which limits statistical comparisons.

The majority of hydroid species in our Kongsfjorden samples were represented by small colonies and could be classified as fouling species, which are closer to 'microepifauna'. Symplectoscyphus tricuspidatus var. acuminatus is 
Phylum CNIDARIA

Subphylum MEDUSOZOA

Class HYDROZOA

Subclass HYDROIDOLINA

Order ANTHOATHECATA

Suborder FILIFERA

Family CLAVIDAE

Rhizogeton nudum Broch, 1910

Family HYDRACTINIIDAE

Hydractinia carica Bergh, 1887

Family PANDEIDAE

Halitholus cirratus Hartlaub,

$$
1914
$$

Family BOUGAINVILLIIDAE

Garveia sp.

Stolonal

Arctic-Boreal

Stolonal

Arctic

Family EUDENDRIIDAE

Eudendrium vaginatum Allman,

Stolonal

Boreal-Arctic

Stolonal

Bushy

Family STYLASTERIDAE

Stylasteridae sp. gen.

Arborescent

Suborder CAPITATA

Family CORYNIDAE

Sarsia tubulosa (M. Sars, 1835)

Stolonal

$$
\begin{aligned}
& \text { Bipolar or Circumpolar } \\
& \text { and Boreal of } \\
& \text { Northern }
\end{aligned}
$$

Hemisphere

Family CANDELABRIDAE

Candelabrum phrygium

(Fabricius, 1780)

Solitary

Circumpolar BorealArctic

Order LEPTOTHECATA

Hydrozoa Lepothecata sp. gen

Suborder PROBOSCOIDEA

Family CAMPANULARIIDAE

Campanularia volubilis

Orthopyxis integra (MacGillivray,

$$
\text { 1842) }
$$

Obelia longissima (Pallas, 1766)

Laomedea flexuosa Alder, 1857

Stolonal

Low-Boreal-Arctic

Stolonal

Arborescent

Bushy

Boreal-Arctic

Bipolar

Boreal-Arctic

Locality

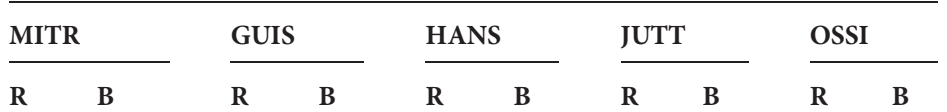

$1 \quad 0.24$

$1 \quad 3.20$

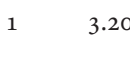

$1 \quad 0.04$

1

0.04

$1 \quad 0.04$

0.93

$1 \quad 3.60$ 


\begin{tabular}{|c|c|c|c|c|c|c|c|c|c|c|c|c|c|c|c|c|}
\hline 13 & Clytia gracilis (M. Sars, 1850) & Stolonal & Panoceanic & & & & & 1 & 0.20 & & & & & 1 & 0.20 & 25 \\
\hline & $\begin{array}{l}\text { Suborder CONICA } \\
\text { Family CAMPANULINIDAE }\end{array}$ & & & & & & & & & & & & & & & \\
\hline 14 & $\begin{array}{l}\text { Calycella syringa (Linnaeus, } \\
1767 \text { ) }\end{array}$ & Stolonal & Bipolar & 1 & 0.04 & & & & & & & & & 1 & 0.04 & 5 \\
\hline 15 & $\begin{array}{l}\text { Family PHIALELLIDAE } \\
\text { Phialella quadrata (Forbes, 1848) }\end{array}$ & Stolonal & Low-Boreal-Arctic & & & & & 1 & 0.08 & 1 & 0.28 & & & 2 & 0.36 & $0.5-2.5$ \\
\hline & Family LAFOEIDAE & & & & & & & & & & & & & & & \\
\hline 16 & Filellum serpens (Hassal, 1848) & Stolonal & Bipolar & 5 & 0.14 & 2 & 0.10 & 1 & 0.08 & 1 & 0.20 & & & 9 & 1.16 & $2.5-20$ \\
\hline 17 & $\begin{array}{l}\text { Grammaria abietina (M. Sars, } \\
1850 \text { ) }\end{array}$ & Bushy & $\begin{array}{l}\text { Bipolar or Boreal- } \\
\text { Arctic }\end{array}$ & & & & & 2 & 1.20 & & & & & 2 & 2.40 & $25-30$ \\
\hline 18 & Lafoea dumosa (Fleming, 1820) & Stolonal & $\begin{array}{l}\text { Panoceanic (obliqua- } \\
\text { arctic ssp.) }\end{array}$ & 4 & 1.02 & 1 & 0.80 & 9 & 0.94 & 2 & 1.10 & & & 16 & 15.52 & $2.5-30$ \\
\hline 19 & $\begin{array}{l}\text { Family SERTULARIIDAE } \\
\text { Sertularella rugosa (Linnaeus, } \\
\text { 1758) }\end{array}$ & Bushy & Boreal-Arctic & 2 & 1.20 & & & 2 & 1.20 & & & & & 4 & 4.80 & $1.3-10$ \\
\hline 20 & $\begin{array}{l}\text { Symplectoscyphus tricuspidatus } \\
\text { var. acuminatus } \\
\text { (Kirchenpauer, 1884) }\end{array}$ & Bushy & High-Boreal-Arctic & 4 & 122.00 & 2 & 1.40 & 2 & 3.00 & & & & & 8 & 496.80 & $1.3-5$ \\
\hline & Family HALECIIDAE & & & & & & & & & & & & & & & \\
\hline 21 & Halecium labrosum Alder, 1859 & Bushy & Low-Boreal-Arctic & 4 & 0.32 & & & 4 & 0.54 & & & & & 8 & 3.44 & $1.3-30$ \\
\hline 22 & Halecium tenellum Hincks, 1861 & Poorly bushy & Bipolar & 1 & 0.80 & & & & & & & & & 1 & 0.80 & 2.5 \\
\hline 23 & $\begin{array}{l}\text { Halecium halecinum (Linnaeus, } \\
\text { 1758) }\end{array}$ & Bushy & Boreal-Arctic & & & & & 1 & 0.40 & & & & & 1 & 0.40 & 30 \\
\hline & Halecium sp. juv. & Stolonal & - & & & 1 & 0.08 & 1 & 0.12 & & & & & 2 & 0.20 & $2.5-25$ \\
\hline Total & & & & 37 & 13.59 & 17 & 0.65 & 42 & 0.73 & 9 & 0.68 & 4 & 0.06 & 109 & 550.89 & $0-30$ \\
\hline
\end{tabular}

$\mathrm{R}$, species occurrence in samples; $\mathrm{B}\left(\mathrm{g} \mathrm{m}^{-2}\right)$, mean weight of species per sample; $\sum \mathrm{R}$, total occurrence of species in samples; $\sum \mathrm{B}\left(\mathrm{g} \mathrm{m}^{-2}\right)$, total weight of species; $\mathrm{D}(\mathrm{m})$, minimum-maximum depth of species records. 
one of two species in our samples that could be considered as macrofauna. Together with Candelabrum phrygium, they could be referred to 'macroepifauna' based on their large size and weight.

Symplectoscyphus tricuspidatus (Alder, 1856) is mentioned by Linko $(1911,1912)$ and Naumov $(1960)$ as a species that forms abundant colonies with high biomass at 25-100 $\mathrm{m}$ depth in the North Atlantic around Bear Island, Nordkapp, and at the Murman coast in Kola Bay. According to our data, S. tricuspidatus var. acuminatus also can form large colonies. Colonies of this species at $2.5 \mathrm{~m}$ deep at MITR had a biomass of $480 \mathrm{~g} \mathrm{~m}^{-2}$, occupied the majority of substratum, and were abundant enough to serve as habitat for other zoobenthic organisms. The presence of abundant colonies of this species in the upper part of the transect MITR likely reflects the influence of the West Spitsbergen Current on communities in the outer part of the fjord. The structure they provide is a defining feature of this community.

Hydroids are mainly passive carnivores, and when they are numerous they could be important for transfer of energy to upper trophic levels (Bouillon et al., 2004 cited in Ronowicz, 2007). In order to accurately describe the composition of the entire fjord ecosystem, we think it is important to emphasize species that could be abundant, and could, therefore, be important in determining the structure and function of separate communities within the fjord. Stolonal colonies as a rule do not develop colonies with high biomass. High hydroid biomass is most likely to occur in bushy or arborescent colonies, represented in 10 species of the 23 species we collected. For Obelia longissima, there are some published records about populations with high biomass. In the White Sea, in natural habitats as well as on artificial hard substrata, biomass of $O$. longissima could reach $500-700 \mathrm{~g} \mathrm{~m}^{-2}$ (Letunov \& Stepanjants, 1986; Stepanjants \& Letunov, 1989). The annual growth on artificial substrata in the Barents Sea is up to $500 \mathrm{~g} \mathrm{~m}^{-2}$ (Panteleeva, 1999). Kunin (1999) gives examples of $O$. longissima biomass $>340 \mathrm{~g} \mathrm{~m}^{-2}$ in Avacha Bay (Kamchatka, Russia), and the Japan Sea, but in Kongsfjorden we have found no habitats with colonies $>$ $0.1 \mathrm{~g}$.

Our data show that S. tricuspidatus var. acuminatus is probably the only hydroid species that is important for energy transfer between trophic levels in the ecosystem of Kongsfjorden. In other localities except MITR, however, colonies were generally small $(0.2-1.0 \mathrm{~g})$. In 7 locations sampled, S. tricuspidatus var. acuminatus is not a substratum species, but is fouling like most other species of Hydrozoa. Despite their high occurrence in Kongsfjorden, other hydroid species do not produce high biomass in investigated biocenoses. The weight of colonies ranged from $<0.001 \mathrm{~g}$ to $0.9 \mathrm{~g}$.

In addition to 10 species with bushy and arborescent colonies, one species was represented by solitary polyps and 12 species had stolonal colonies. The species with bushy-arborescent colonies were less common on transects in the inner fjord than in the outer fjord. On transects JUTT and OSSI, bush-arborescent species were recorded in $12.5 \%$ and $25 \%$ of the samples, respectively. On transects from outer and middle parts of the fjord, their frequency of occurrence was $37.5-43.2 \%$.

It was expected that hydroids, which are mainly epibionts, are not independent components of zoobenthic assemblages. Our data show that some features of hydroid diversity are linked to the type of zoobenthic community (Table 2). ANOSIM for presence-absence of hydroid species shows significant differences among communities $(\mathrm{r}=0.288, P<0.01)$.

Seven main community types have been determined for hard substrata in Kongsfjorden (A. Voronkov, unpublished data). One of the community types was defined based on the dominance of branched hydroid colonies of Symplectoscyphus tricuspidatus var. acuminatus. This dominant species was accompanied by only one other hydroid species, Eudendrium vaginatum.

Two communities, 'Balanus balanus community' and 'branched bryozoans community' are characterized by a high percentage of samples containing hydroids and, accordingly, high species richness (Table 2). The difference between these two communities is that the community dominated by the branched bryozoans (Tricellaria ternanta and Eucratea loricata mainly) was located at relatively shallow depths within a well-developed kelp belt, whereas the community dominated by Balanus balanus occupied deeper habitats with much less kelp. The largest number of hydroid species per sample characterized the branched bryozoan community. The Balanus balanus community, as a rule, has a greater spatial complexity than the branched bryozoan community. The frequency of hydroid species occurrence in samples, however, was approximately two times higher in the branched bryozoan community than in the Balanus balanus community. Ronowicz et al. (2008) mentioned that bryozoans attached to macroalgae were preferred secondary substratum for hydroid settlement in Hornsund fjord and this conclusion is supported by our data.

Another type of community with high total hydroid species richness is the 'impoverished' community. This community is characterized by the absence of a dominant species, low diversity and very low biomass of zoobenthos. These features do

Table 2. Hydrozoa distribution within different zoobenthic communities in Kongsfjorden, Svalbard.

\begin{tabular}{|c|c|c|c|c|c|c|c|}
\hline Community type & $\mathbf{1}$ & 2 & 3 & 4 & 5 & 6 & 7 \\
\hline Total number of samples & 1 & 23 & 10 & 3 & 13 & 8 & 5 \\
\hline Per cent of samples containing hydroids & 100.0 & 82.6 & 90.0 & $33 \cdot 3$ & 38.5 & 37.5 & 40.0 \\
\hline Species richness & 2 & 12 & 12 & 3 & 13 & 6 & 4 \\
\hline Occurrence of Anthoathecata species in samples & 1 & 4 & 3 & 1 & 4 & 3 & 1 \\
\hline Occurrence of Leptothecata species in samples & 1 & 34 & 32 & 2 & 13 & 3 & 3 \\
\hline Mean occurrence of hydroid species per sample & 2.00 & 1.65 & 3.50 & 1.00 & 1.31 & 0.75 & 0.80 \\
\hline Mean biomass per sample $\left(\mathrm{g} \mathrm{m}^{-2}\right)$ & 480.80 & 1.04 & 2.18 & 0.12 & 1.27 & 0.08 & 1.30 \\
\hline
\end{tabular}

1, Symplectoscyphus community; 2, Balanus balanus community; 3, branched bryozoans community; 4, 'developed' community; 5, 'impoverished' community; 6, Gammaridae community; 7, Bivalvia community. 


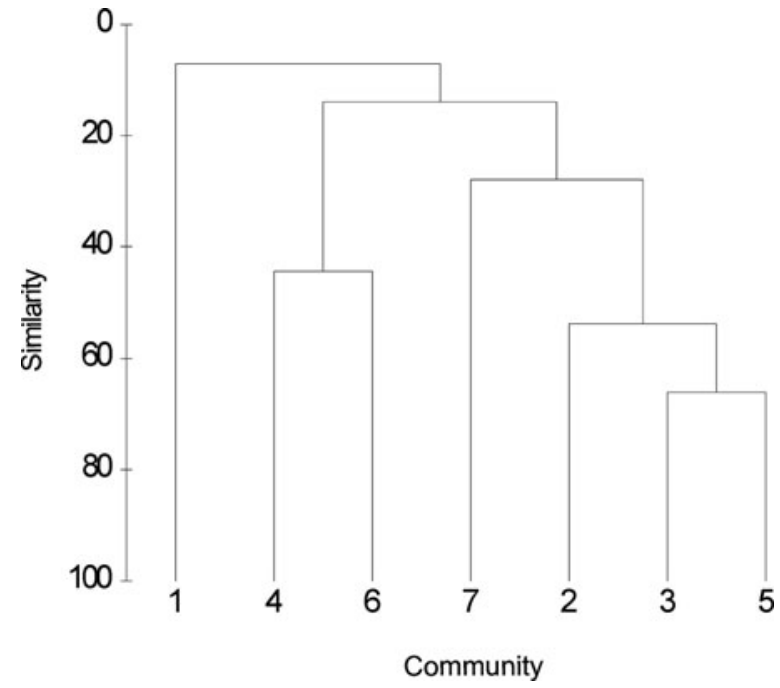

Fig. 2. Cluster plot of similarity in hydroid species composition for different zoobenthic communities (presence-absence of species in samples, BrayCurtis similarity, square root transformation, group averaging mode, \%). (1) Symplectoscyphus community; (2) Balanus balanus community; (3) branched bryozoans community; (4) 'developed' community; (5) 'impoverished' community; (6) Gammaridae community; (7) Bivalvia community.

not prevent development of hydroid colonies, but high species richness in samples is uncommon (Table 2). Only 5 out of 13 samples contained hydroids, which resulted in a low mean number of species per sample.

The 'developed' community type is characterized by high diversity and biomasses of zoobenthos without a definite dominant species. This community was found in three samples, with hydroids in only one sample, making it impossible to draw any conclusions regarding the relationship between hydroid abundance and this community type.

Another two communities are characterized by low species richness, low number of species records in samples and low percentage of samples with hydroids. These are the 'Gammaridae community' from bedrock habitats at the shallowest parts of transects, and the 'Bivalvia community' from gravel substrata at the bottom of transects.

Similarity analysis of hydroid species composition in different communities (Figure 2) showed the highest similarity for three communities where hydroids were abundant. The shallow branched bryozoan community and 'impoverished' community are more similar in hydroid composition to each other than to the Balanus balanus community, which is found deeper at depths of 10 to $30 \mathrm{~m}$. Based on SIMPER analysis, the most important species contributing to hydroid similarity among samples within the branched bryozoan community are Orthopyxis integra (28.8\%) and Campanularia volubilis (27.3\%). For the 'impoverished' community the most important species are Orthopyxis integra (25.0\%) and Halecium labrosum (25.0\%). The Balanus balanus community differed from them in that Lafoea dumosa was the most important species contributing to $60.3 \%$ of similarity among samples within this community type.

Hydroids were found on all 5 transects. Analysis of species distribution and biomass indicated a reduced diversity of hydroids on hard substrata in the inner part of the fjord compared to the outer fjord (Table 3). At HANS, MITR and GUIS, transects from the outer and middle parts of the fjord, hydroids were characterized by highest species richness and highest mean occurrence of species per sample (although differences were not statistically significant because of high variation and limited number of sampling replicates). The largest number of hydroid species (5-9 per sample) was found at shallow depths on transects from the outer and middle parts of fjord: at MITR at 2.5 and $5 \mathrm{~m}$ depths, at GUIS at $2.5 \mathrm{~m}$ depth, and at HANS at 1.3 and $2.5 \mathrm{~m}$ depth. Some characteristics, however, such as percentage of samples with hydroids or mean biomass of species per sample, gave similar values for transects from the inner part of the fjord (JUTT and OSSI) and transect GUIS from the middle part of the fjord. The zoobenthic diversity generally decreased from the outer to inner parts of Kongsfjorden (A. Voronkov, unpublished data), but hydroid diversity did not appear to follow this pattern. The highest species richness and number of samples containing hydroids were on transect HANS from the middle part of the fjord. At the same time, transect GUIS, which is closer to the fjord's outlet than HANS, is characterized by a lower Hydrozoa diversity. The analysis of similarity in species composition revealed higher similarity between transects MITR and HANS, which are further away from each other than between transect GUIS and HANS (Figure $3 \mathrm{~A}$ ). This pattern could partly be explained by our sampling design. We focused our collection on random habitats at specific depths. This resulted in a lower percentage of samples from habitats dominated by barnacles $(5$ samples from transect GUIS compared to 7 and 11 from transects MITR and HANS, respectively) than if we had targeted specific habitats. The Balanus balanus community contained relatively high diversity of hydroids. The lower number of samples within this community at GUIS could lead to an underestimate of hydroid diversity. A more accurate analysis of Hydrozoa diversity on transects was difficult due to differences in the number of samples collected from the different communities along transects.

Hydroids occurred at all depths from o to $30 \mathrm{~m}$. Mean occurrence and biomass of Hydrozoa species was higher at shallow depths (except o m) than at deeper locations (Table 4). Low species occurrence and biomass were found

Table 3. Hydrozoa distribution by transects in Kongsfjorden, Svalbard.

\begin{tabular}{|c|c|c|c|c|c|}
\hline Transect & MITR & GUIS & HANS & JUTT & OSSI \\
\hline Total number of samples & 14 & 16 & 17 & 10 & 6 \\
\hline Per cent of samples containing hydroids & 78.6 & 43.8 & 94.1 & 30.0 & 50.0 \\
\hline Species richness & 11 & 9 & 15 & 7 & 4 \\
\hline Occurrence of Anthoathecata species in samples & 5 & 4 & 3 & 2 & 3 \\
\hline Occurrence of Leptothecata species in samples & 32 & 11 & 38 & 6 & 1 \\
\hline Mean occurrence of hydroid species per sample & 2.64 & 0.94 & 2.41 & 0.80 & 0.67 \\
\hline Mean biomass per sample $\left(\mathrm{g} \mathrm{m}^{-2}\right)$ & 35.91 & 0.69 & 1.80 & 0.62 & 0.04 \\
\hline
\end{tabular}




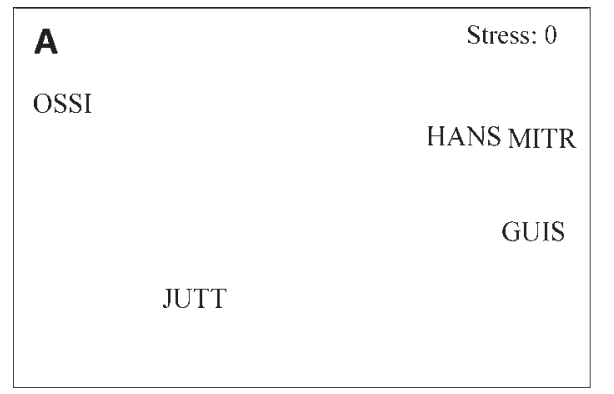

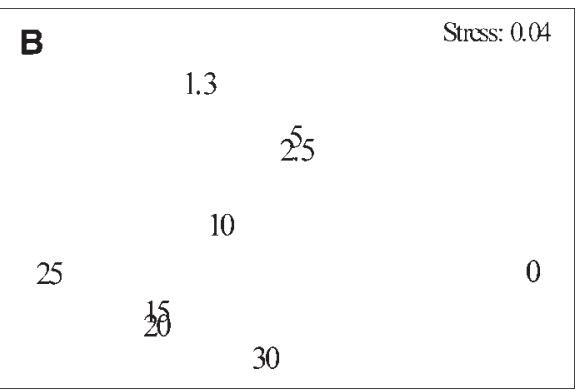

Fig. 3. Multidimensional scaling plot of similarity in hydroid species composition in Kongsfjorden, Svalbard, for (A) for transects, and (B) depths (m).

Table 4. Hydrozoa distribution by depths $(\mathrm{m})$ in Kongsfjorden, Svalbard.

\begin{tabular}{|c|c|c|c|c|c|c|c|c|c|}
\hline Depth (m) & o & 1.3 & 2.5 & 5 & 10 & 15 & 20 & 25 & 30 \\
\hline Total number of samples & 8 & 1 & 10 & 11 & 8 & 7 & 6 & 6 & 6 \\
\hline Per cent of samples containing hydroids & 37.5 & 100.0 & 80.0 & 63.6 & 62.5 & 71.4 & 50.0 & 66.7 & 66.7 \\
\hline Species richness & 6 & 5 & 13 & 10 & 7 & 5 & 5 & 5 & 6 \\
\hline Occurrence of Anthoathecata species in samples & 3 & 1 & 4 & 4 & 1 & 2 & 1 & 1 & 0 \\
\hline Occurrence of Leptothecata species in samples & 3 & 4 & 28 & 15 & 10 & 5 & 6 & 6 & 11 \\
\hline Mean occurrence of hydroid species per sample & 0.75 & 5.00 & 3.20 & 1.73 & 1.38 & 1.00 & 1.17 & 1.17 & 1.83 \\
\hline Mean biomass per sample $\left(\mathrm{g} \mathrm{m}^{-2}\right)$ & 0.08 & 5.68 & 49.87 & 1.12 & 0.74 & 0.83 & 1.07 & 1.14 & 1.40 \\
\hline
\end{tabular}

at $15 \mathrm{~m}$ depth with a slight increase for deeper samples (Figure 4). The pattern seen in hydroids is a reflection of the general tendency for zoobenthos diversity to decline at 15-20 m depth in Kongsfjorden (e.g. Gontar et al., 2001, for Bryozoa). The distributional patterns for Leptothecata and Anthoathecata were similar.

The proposed reason for depleted diversity at 15-20 m depth is that these depths fall between different water masses (i.e. freshened surface water versus deeper, more saline water). The dissimilarity between species composition in samples above $15 \mathrm{~m}$ depth ('shallow') and below $15 \mathrm{~m}$ ('deep') was high (Figure 3 B). In accordance with SIMPER analysis, the average dissimilarity value was 85.9. Orthopyxis integra, Symplectoscyphus tricuspidatus var. acuminatus and Filellum serpens contributed to $63.5 \%$ of similarity within group of 'shallow' samples. Lafoea dumosa and Campanularia volubilis contributed together to $89.7 \%$ of similarity within group of 'deep' samples. 'Shallow' samples were more diverse in hydroid species composition. Average

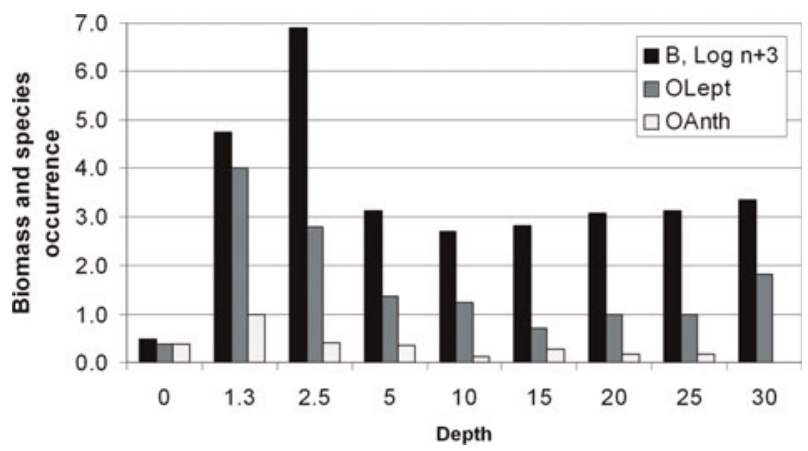

Fig. 4. Distribution of biomass and occurrence of hydroid species in samples by depth. $\mathrm{B}, \log \mathrm{n}$, mean biomass, $\log \mathrm{n}+3 \mathrm{~g} \mathrm{~m}^{-2}$; OLept, occurrence of Leptothecata species, mean number of species records per sample; OAnth, occurrence of Anthoathecata species, mean number of species records per sample. similarity between samples was 17.0 , compared to 23.5 in case of 'deep' samples. Hydroids with an Arctic distribution were collected only deeper than $15 \mathrm{~m}$, suggesting that the deeper and shallower water masses are different.

Species with different biogeographical characteristics (Table 1) can be divided into 5 groups (Figure $5 \mathrm{~A}$ ). Widespread Boreal-Arctic species comprised half of total
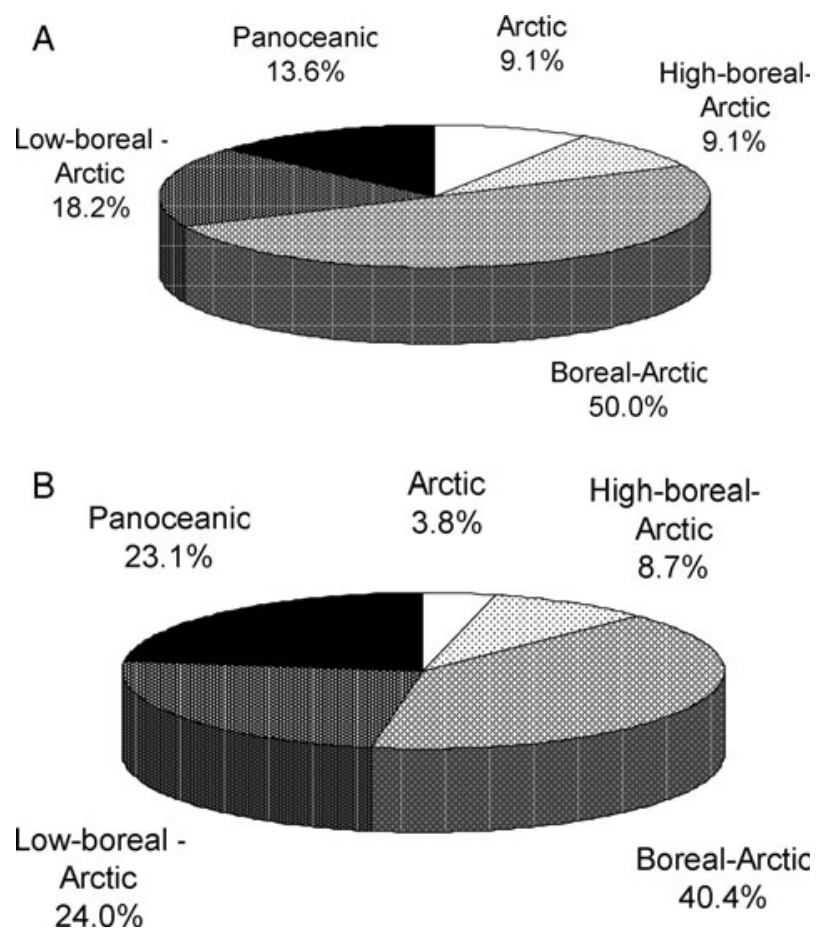

Fig. 5. Biogeographical composition of hydroids on hard substrata in Kongsfjorden, Svalbard. (A) Relative contribution to total hydroid species richness; (B) relative contribution to mean number of hydroid species records per sample. 

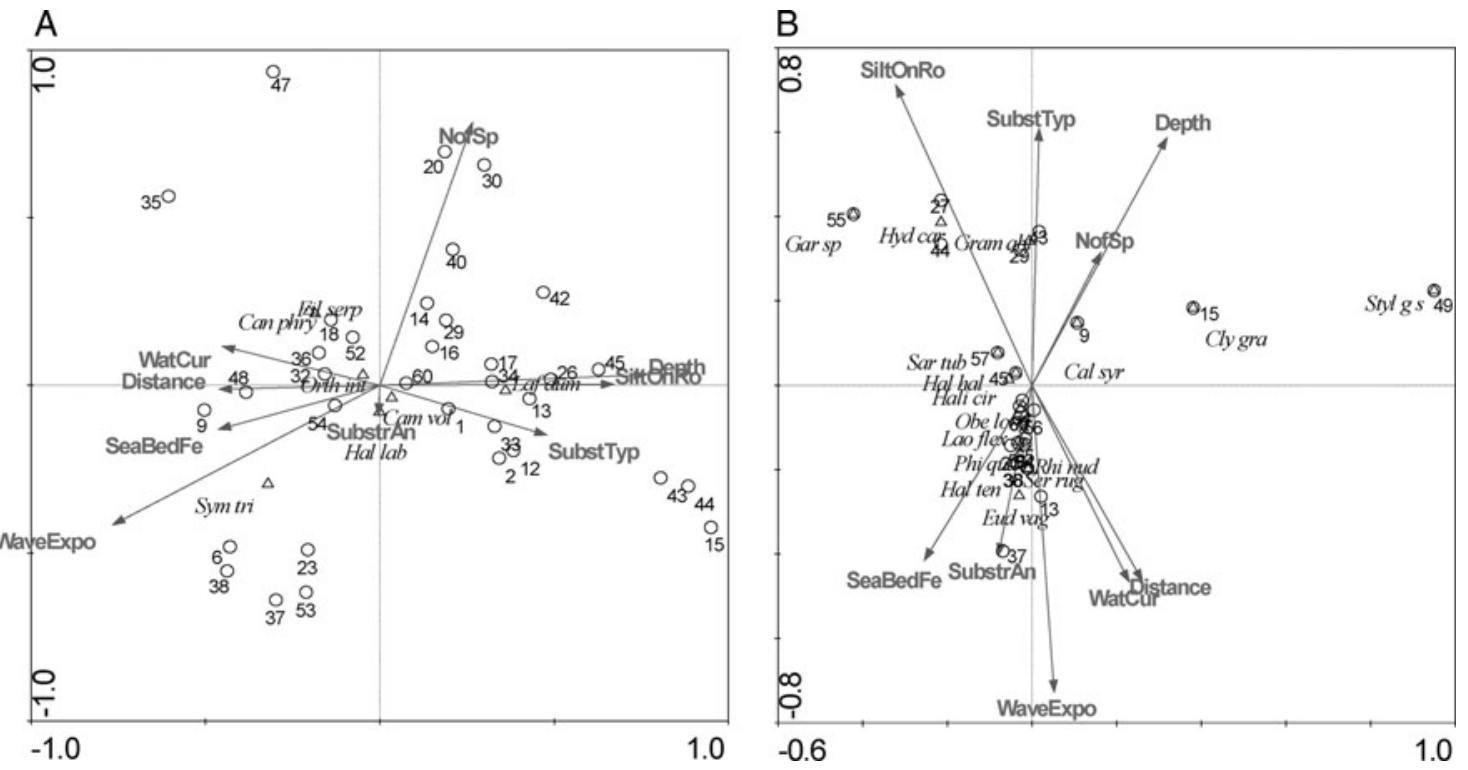

Fig. 6. Canonical correspondence analysis plot for presence-absence of hydroid species in samples from Kongsfjorden, Svalbard. (A) The 7 most widespread hydroid species (focus on inter-species distances, square root transformation); (B) the 16 rare hydroid species (focus on inter-species distances, no transformation). Acronyms of factors are the same as in Appendix 1.

species richness. Species with an even wider range of distribution, Low-boreal-Arctic and Panoceanic species, accounted for one-third $(31.8 \%)$ of total species richness. Cold-water Arctic and High-boreal-Arctic species contributed $<_{20} \%$ ( $18.2 \%$ together). A similar picture is revealed based on the frequency of occurrence of species in samples, although the Low-boreal-Arctic and Panoceanic species were proportionally more common and the Arctic and Boreal-Arctic less common than in distributions based on total species richness (Figure ${ }_{5} \mathrm{~B}$ ). Species with very wide tolerance limits comprise almost half of the species records in samples $(47.1 \%)$. However, no definite patterns were revealed with regard to distribution of species with different biogeographical characteristics on transects along environmental gradients.

Canonical correspondence analysis illustrates the relationship between species and environmental variables. The plots for widespread and rare hydroid species are presented separately (Figure 6A, B) to make charts more readable. The statistical significance of the relationships among hydroid species and environmental variables were evaluated using a Monte-Carlo permutation test. The test revealed a statistically significant relationship $(P<0.05)$ between the distribution of species by sampling localities and the level of wave exposure in the case of widespread species (Figure 6A). In the case of rare species (Figure 6B), the distribution of species was significantly related to depth as well as distance from the tidal glacier. When widespread and rare species are considered together, depth, amount of silt on the surface of substratum and the type of background substratum are all significantly related to the presence or absence of hydroid species. Depth was not a significant factor for Hydrozoa diversity in Hornsund fjord (Ronowicz et al., 2008), but samples were only collected over a range of 5-10 $\mathrm{m}$ depth which is likely too narrow for significant differences in diversity.

The CCA plot also summarizes the distribution of different species, and it is clear that Lafoea dumosa has a different distribution from other abundant hydroid species in relation to some environmental factors. In Kongsfjorden, L. dumosa prefers deep and flat (not steep) habitats. This species inhabits sheltered conditions where some silt on the substratum surface does not prevent growth of $L$. dumosa colonies. Symplectoscyphus tricuspidatus var. acuminatus tolerates unstable conditions of most shallow habitats better than other species. Filellum serpens and Candelabrum phrygium, in contrast to Halecium labrosum, prefer well developed species-rich zoobenthic communities. More detailed data on distribution of hydroid species in Kongsfjorden are presented in Appendix 2.

The baseline study of the zoobenthic diversity on hard substrata in Kongsfjorden revealed wide distribution of hydroid species in studied habitats. Hydrozoan diversity was connected to the type of benthic community. Patterns of hydroids distribution were closely related to the general zoobenthic distributional patterns with regard to environmental gradients. The general benthic sampling gave evidence of hydroid dominance in selected habitats. However, additional, specific hydrozoan sampling with more replicates is desirable to make more precise conclusions about their role in the benthic communities of the study area.

\section{ACKNOWLEDGEMENTS}

We thank SCUBA divers Michael Poltermann, Nikolaj A. Kovaltchouk and Bjørnar Seim who participated in sample collections together with Dive Leader Haakon Hop. We are grateful to taxonomists at the Laboratory of Marine Research (ZIN RAS) for identification of all zoobenthic groups that made possible an analysis of communities and N.A. Kovaltchouk (Komarov Botanical Institute, RAS) who provided the list of algal species collected within sampling sites. Sverdrup Station, Norwegian Polar Institute, in Ny-Ålesund, Svalbard, is acknowledged for logistic support. This project was funded by Arctic Light and Heat 
Programme and Eastern Europe Programme of the Research Council of Norway, and StatoilHydro ARCTOS Arctic Research Programme (SAARP). The publication was possible because of the support of the Norwegian Polar Institute and ARCTOS PhD Trainee School. The help of Professor William G. Ambrose Jr (Bates College, USA) in editing earlier drafts is appreciated very much. The comments of anonymous referees greatly helped to improve the manuscript.

\section{REFERENCES}

Assmann M. (2004) The sponge community of a semi-submerged cave in Kongsfjorden, Svalbard. In Wiencke C. (ed.) The coastal ecosystem of Kongsfjorden, Svalbard. Synopsis of the biological research at the Koldewey Station in the years 1991-2003. Berichte zur Polar- und Meeresforschung 492, 86-90.

Birula A.A. (1897) Hydrozoa, Polychaeta, and Crustacea collected by Dr. A.S. Botkin in Enisean and Ob gubi (bays) during the summer 1895 Materials for the biology and zoogeography of the Russian Seas mainly. Annual of the Zoological Museum of the Academy of Sciences, St Petersburg 2, 78-115.

Birula A.A. (1900) Route of voyage of senior-zoologist A.A. Birula to the Spitzbergen Islands in 1899. Annual of the Zoological Museum of the Imperial Academy of Sciences 1899, 1-8.

Blazewicz-Paszkowycz M. and Sekulska-Nalewajko J. (2004) Tanaidacea (Crustacea, Malacostraca) of two polar fjords: Kongsfjorden (Arctic) and Admiralty Bay (Antarctic). Polar Biology 27, 222-230.

Bonnevie K. (1898) Zur Systematic der Hydroiden. Zeitschrift für Wissenschaftliche Zoologie 63, 465-495.

Bonnevie K. (1899) Hydroida. Den Norske Nordhavs-Expedition 1876 1878. Zoologi 7, 1-103.

Bouillon J., Medel M.D., Pages F., Gili J.M., Boero F. and Gravili C. (2004) Fauna of the Mediterranean Hydrozoa. Scientia Marina 68, $1-449$.

Broch H. (1910) Die Hydroiden der arktischen Meere. Fauna Arctica 5 129-248.

Broch H. (1918) Hydroida (Part II). The Danish Ingolf-Expedition 5 , 3-205.

Carlsen B.P., Johnsen G., Berge J. and Kuklinski P. (2007) Biodiversity patterns of macro-epifauna on different lamina parts of Laminaria digitata and Saccharina latissima collected during spring and summer 2004 in Kongsfjorden, Svalbard. Polar Biology 30, 939-943.

Christiansen B.O. (1972) The Hydroid Fauna of the Oslo Fiord in Norway. Norwegian Journal of Zoology 20, 279-310.

Clarke K.R. and Warwick R.M. (2001) Change in marine communities: an approach to statistical analysis and interpretation, 2nd edition. Plymouth: PRIMER-E.

Cornelius P.F.S. (1995) North-West European thecate hydroids and their medusae. Part 2. Sertulariidae to Campanulariidae. In Barnes R.S.K. and Crothers J.H. (eds) Synopses of the British Fauna (New Series). London: E.J. Brill/W. Backhuys, pp. 1-386.

Gontar V.I., Hop H. and Voronkov A.Y. (2001) Diversity and distribution of Bryozoa in Kongsfjorden, Svalbard. Polish Polar Research 22, $187-204$.

Gulliksen B., Haug T. and Sandnes O.K. (1980) Benthic fauna on new and old lava grounds at Jan Mayen. Sarsia 65, 137-148.

Hansen J.R. and Haugen I. (1989) Some observations of intertidal com munities on Spitsbergen $\left(79^{\circ} \mathrm{N}\right)$, Norwegian Arctic. Polar Research 7 $23-27$.
Hop H., Pearson T., Hegseth E.N., Kovacs K.M., Wiencke C., Kwasniewski S., Eiane K., Mehlum F., Gulliksen B., Wlodarska-Kowalczuk M., Lydersen C., Weslawski J.M., Cochrane S., Gabrielsen G.W., Leakey R.J.G., Lønne O.J., Zajaczkowski M., Falk-Petersen S., Kendall M., Wängberg S.-Å., Bischof K., Voronkov A.Y., Kovaltchouk N.A., Wiktor J., Poltermann M., di Prisco G., Papucci C. and Gerland S. (2002) The marine ecosystem of Kongsfjorden, Svalbard. Polar Research 21, 167-208.

Jäderholm E. (1908) Die Hydroiden des sibirischen Eismeeres, gesammelt von der Russischen Polar-Expedition 1900-1903. Mémoires de l'Académie Imperiale des Sciences de St Petersbourg 18, 1-27.

Jäderholm E. (1909) Northern and arctic invertebrates in the collection of the Swedish state museum (Riksmuseum). IV. Hydroiden. Kungliga Svenska Vitenskapsakademiens Handlingar 45, 1-124.

Jäderholm E. (1916) Die Hydroiden der Eisfjord. Zoologische Ergebnisse der Schwedischen Expedition nach Spitzbergen. Kungliga Svenska Vitenskapsakademiens Handlingar 54, 1-14.

Jørgensen L.L. and Gulliksen B. (2001) Rocky bottom fauna in Arctic Kongsfjorden (Svalbard) studied by means of suction sampling and photography. Polar Biology 24, 113-121.

Kaczmarek H., Wlodarska-Kowalczuk M., Legezynska J. and Zajaczkowski M. (2005) Shallow sublittoral macrozoobenthos in Kongsfjord, West Spitsbergen, Svalbard. Polish Polar Research 26, 137-155.

Kedra M. and Murina G.V. (2007) The sipunculan fauna of Svalbard. Polar Research 26, 37-47.

Kramp P.L. (1932) Hydroids: the Godthaab Expedition, 1928. Meddelelser om Grønland, Udgave af Kommissionen for Videnskabelige Undersøgelser i Grønland 79, 1-86.

Kramp P.L. (1942) Medusae. The Godthaab Expedition 1928. Meddelelser om Grønland, Udgave af Kommissionen for Videnskabelige Undersøgelser i Grønland 81, 1-168.

Kudelin N.V. (1914) Hydroidy (Hydroidea). T. II. Fauna Rossii i sopredel'nich stran. Zoologicheskyj Muzej Academii Nauk Rossii. St Peterburg, pp. 139-526.

Kuklinski P. (2002) Fauna of Bryozoa from Kongsfjorden, West Spitsbergen. Polish Polar Research 23, 193-206.

Kunin B.L. (1999) Long-term variation in hydroid biomass of Obelia longissima (Pallas) (Hydrozoa, Thecaphora: Campanulariidae) at early developmental stages of mussel Mytilus edulis L (Bivalvia, Mytiliformes: Mytilidae) mariculture in the White Sea. In Stepanjants S.D. (ed.). Obelia (Cnidaria, Hydrozoa). Phenomenon. Aspects of investigations. Perspectives of employment. Zoosystematica Rossica. Supplement N1, pp. 93-96.

Lagardere J.P. (1968) Les Crustacés de l'Expédition Française R. C. P. 42 Au Spitsberg (été 1966). Bulletin du Centre d'Etudes et de Recherches Scientifiques, Biarritz 7, 155-205.

Letunov V.N. and Stepanjants S.D. (1986) A study of the Obelia longissima (Pallas, 1766) (Hydrozoa, Thecaphora, Campanulariidae). A special features of authecology peculiarity of this species in the White Sea conditions. In Fedjakov V.V. and Naumov A.D. (eds) Ecological investigations of the benthic organisms in the White Sea. Leningrad: Zoological Institute, pp. 17-29.

Linko A.K. (1911) Hydroidy (Hydroidea). T. I. Fauna Rossii i sopredel'nich stran. Zoologicheskyj Muzej Academii Nauk Rossii. St Petersburg, pp. $1-250$

Linko A.K. (1912) Hydroidy (Hydroidea). T. II. Fauna Rossii i sopredel'nich stran. Zoologicheskyj Muzej Academii Nauk Rossii. St Petersburg, pp. $1-138$. 
Lippert H., Iken K., Rachor E. and Wiencke C. (2001) Macrofauna associated with macroalgae in the Kongsfjord (Spitsbergen). Polar Biology 24, 512-522.

Naumov D.V. (1960) Hydroidy i hydromeduzy morskih, solonovatovodnyh i presnovodnyh bassejnov SSSR. Opredeliteli po faune SSSR, isdavaemie Zoologicheskim institutom AN SSSR 70, pp. 1-631.

Naumov D.V. (1969) Hydroids and Hydromedusae of the USSR. Jerusalem: Israel Program for Scientific Translation.

Palerud R., Gulliksen B., Brattegard T., Sneli J.-A. and Vader W. (2004) The marine macro-organisms in Svalbard waters. In Prestrud P., Strøm H. and Goldman H.V. (eds) A catalogue of the terrestrial and marine animals of Svalbard. Tromsø: Norwegian Polar Institute, pp. 5-56.

Panteleeva N.N. (1999) Hydroids of the genus Obelia (Hydroidea, Thecaphora, Campanulariidae) in the Barents Sea. Preprint Murmansk, $42 \mathrm{pp}$

Ronowicz M. (2007) Benthic hydroids (Cnidaria: Hydrozoa) from Svalbard waters biodiversity and distribution. Journal of the Marine Biological Association of the United Kingdom 87, 1089-1094.

Ronowicz M., Wlodarska-Kowalczuk M. and Kuklinski P. (2008) Factors influencing hydroids (Cnidaria: Hydrozoa) biodiversity and distribution in Arctic kelp forests. Journal of the Marine Biological Association of the United Kingdom 88, 1567-1575.

Rylov V.M. (1923) Hydroiden-Athecata Zoologische Ergebnisse der Russischen Expeditionen nach Spitzbergen. Annual Magazine Zoological Museum of Russian Academy of Sciences 24, 140-160.

Sahade R., Stellfeldt A., Tatian M. and Laudien J. (2004) Macro-epibenthic communities and diversity of Arctic Kongsfjorden, Svalbard, in relation to depth and substrate. Berichte zur Polar und Meeresforschung 492, 103-113.

Schuchert P. (2000) Hydrozoa (Cnidaria) of Iceland collected by BIOICE programme. Sarsia 85, 411-438.

Schuchert P. (2001) Hydroids of Greenland and Iceland (Cnidaria, Hydrozoa). Meddelelser om Grønland Bioscience 53, 1-184.
Stepanjants S.D. (1989) Hydrozoa of the Eurasian Arctic Seas. In Herman I. (ed.) The Arctic seas. Climatology, oceanography, geology and biology, New York: Van Nostrand Reinhold, pp. 397-430.

Stepanjants S.D. (2001) Subphylum Medusozoa. Classes Hydrozoa, Siphonophora, Scyphozoa. In Sirenko B.I. (ed.) List of species of freeliving invertebrates of Eurasian Arctic seas and adjacent deep waters. Issledovania Fauni Morey 51, 31-36.

Stepanjants S.D. and Letunov V.N. (1989) Life-history of the White Sea population of Obelia longissima (medusa development). In Koltun V.M., Marfenin N.N. and Stepanjants S.D. (eds) The fundamental investigations of the recent Porifera and Cnidaria. Leningrad: Zoological Institute AN USSR, pp. 115-117.

Stepanjants S.D., Cortese G., Kruglikova S.B. and Bjorklund K.R. (2006) A review of bipolarity concepts: history and examples from Radiolaria and Medusozoa (Cnidaria). Marine Biology Research 2, $200-241$.

Svendsen H., Beszczynska-Møller A., Hagen J.O., Lefauconnier B., Tverberg V., Gerland S., Ørbæk J.B., Bischof K., Papucci C., Zajaczkowski M., Azzolini R., Bruland O., Wiencke C., Winther J.-G. and Dallmann W. (2002) The physical environment of Kongsfjorden-Krossfjorden, an Arctic fjord system in Svalbard. Polar Research 21, 133-166.

Warwick R.M., Emblow C., Feral J.-P., Hummel H., van Avesaath P. and Heip C. (2003) European marine biodiversity research sites. Report of the European Concerted Action: BIOMARE. Implementation and networking of large scale, long term Marine Biodiversity Research in Europe. Yerseke: NIOO-CEME.

and

Wlodarska-Kowalczuk M. (2007) Molluscs in Kongsfjorden (Spitsbergen, Svalbard): a species list and patterns of distribution and diversity. Polar Research 26, 48-63.

Correspondence should be addressed to: A. Voronkov

Norwegian Polar Institute $\mathrm{N}-9296$ Tromsø, Norway email: Andrey.Voronkov@npolar.no 


\section{APPENDIX1}

Characteristics of the hard-bottom sampling locations, Kongsfjorden, Svalbard.

\begin{tabular}{|c|c|c|c|c|c|c|c|c|c|c|}
\hline Location & Distance & SubstTyp & Depth & Community & NofSp & WaveExpo & SeaBedFe & SubstrAn & WatCur & SiltOnRo \\
\hline \multirow{8}{*}{$\begin{array}{l}\text { MITR } \\
79^{\circ} 06^{\prime} \mathrm{N} \\
11^{\circ} 08^{\prime} \mathrm{E}\end{array}$} & \multirow[t]{8}{*}{33} & \multirow[t]{5}{*}{ Subtidal rock } & 2.5 & $1 ; 5$ & $29 ; 40$ & $6 ; 6$ & $2 ; 2$ & $65 ; 45$ & $3 ; 3$ & $1 ; 1$ \\
\hline & & & 5 & $3 ; 3$ & $74 ; 81$ & $6 ; 5$ & $2 ; 2$ & $25 ; 65$ & $3 ; 3$ & $1 ; 1$ \\
\hline & & & 10 & $3 ; 2$ & $74 ; 103$ & $5 ; 5$ & $1 ; 2$ & $5 ; 30$ & $3 ; 4$ & $1 ; 1$ \\
\hline & & & 15 & $5 ; 2$ & $9 ; 100$ & $5 ; 5$ & $1 ; 2$ & $0 ; 10$ & $3 ; 3$ & $1 ; 1$ \\
\hline & & & 20 & 2 & 73 & 4 & 1 & 5 & 3 & 1 \\
\hline & & \multirow[t]{3}{*}{ Subtidal gravel } & 20 & 2 & 58 & 4 & 1 & o & 3 & 1 \\
\hline & & & 25 & $2 ; 2$ & $52 ; 100$ & $4 ; 4$ & $1 ; 1$ & $0 ; 0$ & $3 ; 3$ & $1 ; 1$ \\
\hline & & & 30 & $2 ; 7$ & $81 ; 89$ & $4 ; 4$ & $1 ; 1$ & $0 ; 0$ & $4 ; 4$ & $1 ; 1$ \\
\hline \multirow{9}{*}{$\begin{array}{l}\text { GUIS } \\
79^{\circ} 03^{\prime} \mathrm{N} \\
11^{\circ} 37^{\prime} \mathrm{E}\end{array}$} & \multirow[t]{9}{*}{27} & Intertidal rock & 0 & $6 ; 6$ & $5 ; 15$ & $6 ; 6$ & $2 ; 2$ & $25 ; 15$ & $3 ; 3$ & $1 ; 1$ \\
\hline & & \multirow[t]{4}{*}{ Subtidal rock } & 2.5 & $3 ; 3$ & $32 ; 77$ & $6 ; 6$ & $2 ; 2$ & $30 ; 25$ & $3 ; 3$ & $1 ; 1$ \\
\hline & & & 5 & $3 ; 2$ & $56 ; 134$ & $6 ; 5$ & $2 ; 2$ & $0 ; 20$ & $3 ; 3$ & $1 ; 1$ \\
\hline & & & 10 & $2 ; 2$ & $62 ; 83$ & $5 ; 5$ & $1 ; 2$ & $15 ; 15$ & $3 ; 3$ & $1 ; 1$ \\
\hline & & & 15 & 2 & 108 & 4 & 2 & 25 & 3 & 1 \\
\hline & & \multirow[t]{4}{*}{ Subtidal gravel } & 15 & 5 & 26 & 5 & 1 & 0 & 3 & 1 \\
\hline & & & 20 & $2 ; 5$ & $60 ; 9$ & $5 ; 4$ & $1 ; 1$ & $0 ; 0$ & $3 ; 3$ & $1 ; 1$ \\
\hline & & & 25 & $7 ; 7$ & $55 ; 65$ & $3 ; 3$ & $1 ; 1$ & $10 ; 5$ & $3 ; 3$ & $1 ; 1$ \\
\hline & & & 30 & $7 ; 7$ & $45 ; 79$ & $4 ; 3$ & $1 ; 1$ & $5 ; 0$ & $2 ; 3$ & $2 ; 2$ \\
\hline \multirow{10}{*}{$\begin{array}{l}\text { HANS } \\
78^{\circ} 59^{\prime} \mathrm{N} \\
11^{\circ} 57^{\prime} \mathrm{E}\end{array}$} & \multirow[t]{10}{*}{16} & Intertidal rock & 0 & $6 ; 6$ & $12 ; 11$ & $6 ; 6$ & $2 ; 2$ & $35 ; 5$ & $3 ; 3$ & $1 ; 1$ \\
\hline & & \multirow{7}{*}{ Subtidal rock } & 2.5 & $3 ; 3$ & $44 ; 69$ & $6 ; 6$ & $2 ; 2$ & $15 ; 30$ & $3 ; 3$ & $1 ; 1$ \\
\hline & & & 5 & $3 ; 2$ & $60 ; 82$ & $5 ; 5$ & $1 ; 2$ & $10 ; 15$ & $3 ; 3$ & $1 ; 1$ \\
\hline & & & 10 & $2 ; 2$ & $66 ; 102$ & $5 ; 4$ & $2 ; 2$ & $60 ; 60$ & $3 ; 3$ & $1 ; 2$ \\
\hline & & & 15 & $2 ; 2$ & $74 ; 93$ & $6 ; 4$ & $1 ; 2$ & $30 ; 30$ & $2 ; 3$ & $4 ; 1$ \\
\hline & & & 20 & 2 & 102 & 4 & 2 & 45 & 1 & 4 \\
\hline & & & 25 & 2 & 107 & 3 & 2 & 15 & 3 & 4 \\
\hline & & & 30 & $2 ; 2$ & $106 ; 95$ & $4 ; 3$ & $2 ; 2$ & $30 ; 50$ & $2 ; 3$ & $4 ; 4$ \\
\hline & & \multirow[t]{2}{*}{ Subtidal gravel } & 20 & 2 & 63 & 4 & 1 & 40 & 3 & 4 \\
\hline & & & 25 & 2 & 76 & 4 & 1 & 40 & 2 & 4 \\
\hline \multirow{6}{*}{$\begin{array}{l}\text { JUTT } \\
78^{\circ} 56^{\prime} \mathrm{N} \\
12^{\circ} 18^{\prime} \mathrm{E}\end{array}$} & \multirow[t]{6}{*}{14} & & 0 & $6 ; 6$ & $10 ; 13$ & $4 ; 6$ & $2 ; 2$ & $45 ; 75$ & $2 ; 3$ & $1 ; 1$ \\
\hline & & \multirow[t]{2}{*}{ Subtidal rock } & 2.5 & $3 ; 4$ & $89 ; 55$ & $4 ; 4$ & $1 ; 2$ & $40 ; 15$ & $2 ; 3$ & $4 ; 1$ \\
\hline & & & 5 & $4 ; 4$ & $101 ; 68$ & $4 ; 3$ & $2 ; 2$ & $45 ; 90$ & $3 ; 2$ & $4 ; 3$ \\
\hline & & \multirow[t]{3}{*}{ Subtidal muddy gravel } & 5 & 5 & 35 & 3 & 1 & 30 & 2 & 4 \\
\hline & & & 10 & $5 ; 5$ & $58 ; 62$ & $3 ; 3$ & $1 ; 1$ & $40 ; 30$ & $2 ; 3$ & $5 ; 5$ \\
\hline & & & 15 & 5 & 21 & 2 & 1 & 10 & 2 & 5 \\
\hline \multirow{4}{*}{$\begin{array}{l}\text { OSSI } \\
78^{\circ} 56^{\prime} \mathrm{N} \\
12^{\circ} 25^{\prime} \mathrm{E}\end{array}$} & \multirow[t]{4}{*}{7} & Intertidal rock & o & $6 ; 6$ & $8 ; 2$ & $5 ; 5$ & $2 ; 2$ & $0 ; 60$ & $1 ; 1$ & $1 ; 1$ \\
\hline & & Subtidal rock & 2.5 & 5 & 21 & 4 & 1 & o & 1 & 4 \\
\hline & & Subtidal muddy gravel & 2.5 & 5 & 17 & 4 & 1 & 0 & 2 & 4 \\
\hline & & & 5 & $5 ; 5$ & $33 ; 33$ & $3 ; 1$ & $1 ; 1$ & $10 ; 15$ & $2 ; 2$ & $5 ; 5$ \\
\hline
\end{tabular}

Distance, distance from glacier front ( $\mathrm{km})$; SubstTyp, type of substratum; Depth, depth ( $\mathrm{m})$; Community, type of zoobenthic community ( 1 , Symplectoscyphus community; 2, Balanus balanus community; 3, branched bryozoans community; 4, 'developed' community; 5, 'impoverished' community; 6, Gammaridae community; 7, Bivalvia community); NofSp, number of zoobenthic species in sample; WaveExpo, exposure to tidal waves (1, extremely sheltered; 2 , very sheltered; 3, sheltered; 4, semi-exposed; 5, exposed; 6, very exposed); SeaBedFe, seabed feature (1, gentle slope; 2, steep rock); SubstrAn, angle of substrate inclination in sample frame (degree); WatCur, water current flow (1, 0 m/sec; 2, 0.1-0.5 m/sec; 3, 0.6-1 m/sec; 4, more than $\sim 1 \mathrm{~m} / \mathrm{sec}$ ); SiltOnRo, amount of silt on substrate surface ( 1 , no mud/silt; 2 , only some sediments; 3 , very thin layer on rocks; 4 , thin flocculent layer; 5 , thick cover).

\section{APPENDIX2}

The list of hydroid species found in Kongsfjorden, Svalbard, with data on their ecology, distribution by studied habitats and environmental conditions in samples.

Class HYDROZOA

Subclass HYDROIDOLINA

Order ANTHOATHECATA

Suborder FILIFERA

Family CLAVIDAE

(1) Rhizogeton nudum Broch, 1910

North-Atlantic-Arctic species that inhabits different substrata and usually could be found at depths from littoral to
$40 \mathrm{~m}$. It was found once in Kongsfjorden samples on transect GUIS in the outer part of the fjord, at o $\mathrm{m}$ depth. This was a small colony ( $60 \mathrm{mg}$ ). The main substratum within the collecting site was bedrock with some stones without silt. The habitat was overgrown with brown alga Chordaria flagelliformis and extremely exposed to wave impact. The zoobenthic community with dominance of amphipods was species-poor (15 species) with low biomass $\left(20.6 \mathrm{~g} \mathrm{~m}^{-2}\right)$.

\section{Family HYDRACTINIIDAE}

(2) Hydractinia carica Bergh, 1887

Arctic species that inhabits sublittoral zone at depth range 10-140 m. In Kongsfjorden, it was found in two samples (colonies of $0.8 \mathrm{~g}$ ) from very different locations and habitats 
with different environmental conditions. First one was from the deepest ( $15 \mathrm{~m}$ depth) habitat on transect JUTT (inner part of the fjord), where hard substrata were found. Bedrock was covered by thick layer of silt. The sampling location was very sheltered, with reduced salinity. The zoobenthic community was impoverished, species-poor (21 species), with low biomass and abundance. The other sample was from the middle part of the fjord (transect HANS) with an ordinary salinity regime $(>34 \%$ ) at $20 \mathrm{~m}$ depth. This was a species-rich zoobenthic community (104 species) with high abundance of solitary organisms (13548 ind. $\mathrm{m}^{-2}$ ) and high biomass $\left(3707.3 \mathrm{~g} \mathrm{~m}^{-2}\right)$. Such characteristics are typical for communities with a dominance of cirripedian crustaceans Balanus crenatus. The only similarity between these two samples was the presence of buccinid gastropods, Buccinum cyaneum and Boreotrophon clatrathus. Colonies of Hydractinia carica were collected from these molluscs. That confirms the assumption that the species is eurybiotic but tightly connected to the buccinid hosts.

\section{Family PANDEIDAE}

\section{(3) Halitholus cirratus Hartlaub, 1914}

Polyps of this North-Atlantic-Arctic species grow on different substrata, mainly on the shells of Bivalvia of the genus Portlandia, near the mollusc's siphon at depth range to $100 \mathrm{~m}$. In Kongsfjorden the species was found in two samples from the inner part of the fjord, transects JUTT at $2.5 \mathrm{~m}$ depth and OSSI at $\mathrm{om}$ depth. Both localities had unstable and reduced salinity regimes. Habitats were bedrock exposed to waves without any silt on the rock surface. A small colony ( $0.01 \mathrm{~g}$ ) at OSSI was collected from a stone. At JUTT, a colony of similar size and weight was also not associated with bivalve shells. Zoobenthic communities in these two localities were different. On JUTT, the community was of the 'developed' type, species-rich ( 55 species), with low abundance of non-colonial organisms ( 760 ind. $\left.\mathrm{m}^{-2}\right)$, and intermediate total biomass $\left(457.5 \mathrm{~g} \mathrm{~m}^{-2}\right)$. At OSSI, the zoobenthic community was species-poor, with dominance of amphipods (8 species) with low biomass $\left(22.6 \mathrm{~g} \mathrm{~m}^{-2}\right)$.

\section{Family BOUGAINVILLIIDAE}

(4) Garveia sp.

A very small fragment of a colony was found on transect OSSI at $5 \mathrm{~m}$ depth in the innermost part of the fjord close to the glacier. The absence of polyps and gonophores does not allow identification of the colony to the species level. The reason to attribute the colony as Garveia (=Bimeria) is that the polysiphonic stem is very close to the genus representatives. Our material resembles Bimeria biscayana, or, according to Schuchert's (2001) opinion, Amphinema biscayana. The habitat was gravel and stones covered by a thick layer of silt, very sheltered, with slow currents. There were macroalgae Laminaria saccharina attached to small stones within the sampling site, as well as some red algae, and the majority of fauna was associated with these. It was assumed that the hydroid species together with other zoobenthos could be transported to this inner-fjord area from more outer locations during storms.

Family EUDENDRIIDAE

(5) Eudendrium vaginatum Allman, 1863
Colonies of this widespread Arctic-Boreal species have been recorded from littoral zone to $130 \mathrm{~m}$ depth. In Kongsfjorden it was collected from depths 2.5 and $5 \mathrm{~m}$ on transect MITR from rock and kelp rhizoids. Habitats were bedrock without silt, influenced by waves and currents. The small colonies $(0.1-0.4 \mathrm{~g})$ of the species were part of different species-rich or moderately species-rich communities $(35-81$ species) with different dominant species. The substratum was often covered by the kelp or brown alga Chordaria flagelliformis. The common feature for the communities is that they are influenced by warm Atlantic water masses. There is the evidence that $E$. vaginatum is relatively thermophilic.

\section{Family STYLASTERIDAE}

(6) Stylasteridae sp. gen.

A very small poorly preserved specimen was collected at transect GUIS from the middle part of the fjord. The colony has calciferous skeleton, i.e. belongs to hydrocorals. In our case, the specimen has no characters that allow identification to the genus level. One of two families of hydrocorals, Stylasteridae, is coldwater and could be present in the Arctic. Stylasteridae representatives have not been mentioned earlier for Svalbard area and adjacent waters.

The colony was collected from $25 \mathrm{~m}$ depth on sheltered gravel habitat, free of algae (except for crustose algae), with a strong bottom current and without silt. The distinguishing feature of the community at this habitat was relatively high diversity, abundance and biomass of bivalve molluscs.

\section{Suborder CAPITATA} Family CORYNIDAE

(7) Sarsia tubulosa (M. Sars, 1835)

Polyps of this northern-hemispheral circumpolar and Boreal species (or, probably, bipolar), usually inhabit the littoral zone, but may be found at depths down to $100 \mathrm{~m}$. In Kongsfjorden, the only record was from transect OSSI, innermost part of the fjord, at o $\mathrm{m}$ depth. A very small colony (weight $10 \mathrm{mg}$ ) was sampled from the rock, between Fucus distichus thalli. This was a species-poor habitat (8 species), with dominance of amphipods Gammarus setosus, with very low biomasses and abundances of other zoobenthic species. This is typical for habitats near glacier with unstable environmental conditions and reduced salinity. The localisation of record confirms that this species tolerates waters with large range of salinity (but cannot survive in fresh waters).

Family CANDELABRIDAE

(8) Candelabrum phrygium (Fabricius, 1780)

Circumpolar Boreal-Arctic species, inhabiting littoral zone (but in Boreal waters penetrating deeper to $1000-2000 \mathrm{~m}$ ). In Kongsfjorden it was found in six samples from depths 1.3-15 m. Records were from transects MIRT, GUIS and HANS, from outer and middle parts of the fjord. The habitats were within a well-developed kelp belt with the main substratum bedrock without silt on the surface, exposed to waves and relatively strong currents. Weight of eight solitary polyps ranged from 0.1 to $0.5 \mathrm{~g}$. All these records were from species-rich or moderately species-rich communities (32136 species) with dominance of branched bryozoans or barnacles Balanus balanus, with high abundances and biomass $\left(105.1-10544.9 \mathrm{~g} \mathrm{~m}^{-2}\right)$. Thus, C. phrygium makes a relatively low contribution to the diversity of zoobenthic communities. 


\section{Order LEPTOTHECATA \\ Suborder PROBOSCOIDEA \\ Family CAMPANULARIIDAE \\ (9) Campanularia volubilis (Linnaeus, 1758)}

Low-boreal-Arctic species, recorded between 5 and $650 \mathrm{~m}$ (Cornelius, 1995), for Kongsfjorden was mentioned by Lippert et al. (2001) in samples from the red alga Ptilota gunnery. This is the third most widely distributed hydroid species in Kongsfjorden. Small colonies (2-50 mg) were found in 14 samples from all transects except inner most transect OSSI near the glacier. Most records (12 of 14) were from outer- and middle-fjord transects. Our data extended the upper limit of the species distribution to $2.5 \mathrm{~m}$ depth. This species was equally present within depth range 2.5$30 \mathrm{~m}$ both on subtidal rock and on gravel substrata without silt or with a thin flocculent layer of silt on substratum surface. No definite preference regarding community type was determined.

\section{(10) Orthopyxis integra (MacGillivray, 1842)}

Boreal-Arctic species, which is usually epibiont on different algae and other hydroids colonies. In Kongsfjorden, it was mentioned by Lippert et al. (2001) as Campanularia integra MacGillivray, 1842 in samples from kelp Alaria esculenta and Laminaria digitata as well as on red algae Ptilota gunnery and Phycodrys rubens. Together with Lafoea dumosa, it was the most widely distributed hydroid species in the samples. This species was found in 16 samples from transects MITR, GUIS and HANS in the outer and middle parts of the fjord. Its absence from inner part of the fjord confirms observations that it can be found in different salinities, but not in brackish waters. The species is generally found from the littoral zone to below continental shelf depth. In our Kongsfjorden samples, it was recorded at $1.3-25 \mathrm{~m}$ depth, whereas 12 of 16 records were from depth 1.3-10 m. Habitats included mainly bedrock, exposed or extremely exposed to waves, with strong currents and no silt on surfaces. This species was found mainly as a part of rich communities (44-138 species), within well-developed kelp associations and dominance of branched bryozoans or barnacles Balanus balanus. However, species also forms colonies at $20-25 \mathrm{~m}$ depth, in the absence of kelp with some silt layer on the substratum in more sheltered areas. Biomass of the colonies in samples was $0.01-0.08 \mathrm{~g}$. Despite the relatively wide distribution, the species cannot be considered dominant or subdominant in the ecosystem.

\section{(11) Obelia longissima (Pallas, 1766)}

Bipolar species, limited to cold waters of both hemispheres. It is usually found on kelp, but can occur deeper to $100 \mathrm{~m}$. In Kongsfjorden small colonies ( 0.03 and $0.08 \mathrm{~g}$ ) were recorded in two samples, on transects GUIS at o m depth, and on HANS at $30 \mathrm{~m}$ depth. Environmental conditions at the two locations had little in common except that the main habitat was bedrock without kelp. Exact substratum type where the colonies were collected from was not recorded in this case. Shallow depths at GUIS were overgrown by brown algae Chordaria flagelliformis. This benthic community was species-poor (15 species), with low biomass $\left(20.6 \mathrm{~g} \mathrm{~m}^{-2}\right.$ ) and had a dominance of amphipods Ischyrocerus anguipes. The deeper habitat was species-rich (95 species) with high biomass (1317.2 $\mathrm{g} \mathrm{m}^{-2}$ ) and dominance of barnacles Balanus balanus. In both cases, O. longissima is not in the group of dominant or subdominant species.

\section{(12) Laomedea flexuosa Alder, 1857}

Boreal-Arctic shallow-water species, usually inhabiting algae (especially Fucus). In Kongsfjorden it was found in four samples from the middle- and inner-fjord transects HANS, JUTT and OSSI at shallow depths $(0-2.5 \mathrm{~m})$. Habitats were bedrock within the kelp belt mainly, and these were semiexposed or very exposed to wave impact and with or without silt on the substratum surface. Small colonies (0.03-0.06 g) of L. flexuosa were a part of species-poor or moderately species-rich communities (11-69 species) with different dominant species. Biomass of zoobenthos within the communities also varied significantly (from 4.9 to $457.5 \mathrm{~g} \mathrm{~m}^{-2}$ ), but regardless this species cannot be considered dominant or subdominant.

\section{(13) Clytia gracilis (M. Sars, 1850)}

This nearly Panoceanic species is generally epibiont on algae and colonies of other hydroids, (however pelagic colonies are also known) and inhabits depths of 15 to $1500 \mathrm{~m}$. The only sample with $C$. gracilis in Kongsfjorden was from middle-fjord transect HANS at $25 \mathrm{~m}$ depth. The habitat was pebbles overgrown with the red algae Phycodrys rubens, with slow water current and some silt on the surface of the pebbles. A small colony (0.05 g) was found within the speciesrich zoobenthic community ( 76 species) structured by the dominant cirripedian species Balanus balanus.

\section{Suborder CONICA Family CAMPANULINIDAE (14) Calycella syringa (Linnaeus, 1767)}

Bipolar species (Stepanjants et al., 2006), which prefers cold and temperate waters, and is found at depths range from 4$550 \mathrm{~m}$ (usually at 10-150 m depth). For Kongsfjorden, it was mentioned by Lippert et al. (2001) as Campanularia syringa (Linnaeus, 1767) in samples from kelp Alaria esculenta, Laminaria digitata and from the red algae Ptilota gunnery. In our collections it was found only in the sample from transect MITR at $5 \mathrm{~m}$ depth. The habitat was bedrock overgrown by kelp, strongly influenced by currents and waves, with no silt on the substratum surface. The small colony ( $0.01 \mathrm{~g})$ was recorded from a species-rich community (81 species), with high abundance of non-colonial species $\left(27712\right.$ ind. $\left.\mathrm{m}^{-2}\right)$ and high biomass $\left(2028.9 \mathrm{~g} \mathrm{~m}^{-2}\right)$. The zoobenthic community was dominated by branched bryozoans Tricellaria ternata and Eucratea loricata.

Family PHIALELLIDAE

(15) Phialella quadrata (Forbes, 1848)

Low-boreal-Arctic species, inhabiting depths to10 m. In Kongsfjorden, it was collected from shallow depths of $0.5 \mathrm{~m}$ and $2.5 \mathrm{~m}$. Two small colonies ( $0.02 \mathrm{~g}$ and $0.07 \mathrm{~g}$ ) were found in samples from transects HANS and JUTT, in the middle and inner parts of the fjord, respectively. The community characteristics at both localities were different. One sample was from a relatively sheltered habitat, with a thin flocculent layer of silt on the surface of bedrock. The benthic community was species-rich ( 89 species) with dominance of 
branched bryozoans Eucratea loricata and Tricellaria ternata within well-developed kelp belt. Another sample was characterized by low diversity (11 species), absence of kelp or other macroalgae on bedrock and dominance of amphipods Ischyrocerus anguipes. The biomasses of zoobenthos were also different (456.1 and $27.1 \mathrm{~g} \mathrm{~m}^{-2}$, correspondingly), but in both cases Ph. quadrata was not in the group of dominant or subdominant species.

\section{Family LAFOEIDAE}

\section{(16) Filellum serpens (Hassal, 1848)}

Cosmopolitan (Schuchert, 2001) or bipolar (Stepanjants et al., 2006) species, littoral and sublittoral (but known to $3000 \mathrm{~m}$ ). This epibiont on other hydroid colonies was found in nine samples from all transects in Kongsfjorden except for inner most OSSI. Seven records of the nine were from outer most transects MITR and GUIS. Small colonies (0.01-0.07 g) were collected within the depth range of $2.5-20 \mathrm{~m}$; eight samples from nine, with this species; were from 2.5 to $10 \mathrm{~m}$ depth. In all samples where $F$. serpens was present, two or more hydroid species were found. The substratum of the habitats was bedrock within the well developed kelp belt, mainly without silt on the surface and exposed to currents or waves. The species was mainly found within species-rich communities (69-136 species), with high biomass and abundances of non-colonial species, and with dominance of branched bryozoans (in 6 samples) or barnacles Balanus balanus (in 3 samples).

\section{(17) Grammaria abietina (M. Sars, 1850)}

Bipolar species (Stepanjants et al., 2006), inhabiting soft and hard substrata at $10-1200 \mathrm{~m}$ deep (more often at 50$200 \mathrm{~m}$ ). In Kongsfjorden samples, it was found at $25 \mathrm{~m}$ and $30 \mathrm{~m}$ depth on transect HANS from the middle of the fjord. Two colonies ( $0.3 \mathrm{~g}$ each) were a part of a typical species-rich (106 and 107 species) and high biomass Balanus balanus community. In both localities, bedrock was covered with a thin flocculent layer of silt because of the sheltered character of the habitat, without kelp, but with some red algae Phycodrys rubens.

\section{(18) Lafoea dumosa (Fleming, 1820).}

Panoceanic species, inhabiting depths from 4 to $900 \mathrm{~m}$ (sometimes down to $4000 \mathrm{~m}$ in southern regions, but more often at 10-100 m depth). In our Kongsfjorden samples, it was identified as Lafoea dumosa sensu stricto and as an Arctic subspecies Lafoea dumosa obliqua (Johnson, 1847). Colonies of the subspecies have the same structure as the typical Lafoea dumosa. Hydrotheca morphology was also similar to the typical dumosa. The presence of an operculum on the hydrotheca is the only distinguishing feature of this subspecies. Several taxonomists (Jäderholm, 1908, 1909; Broch, 1918; Kramp, 1932) supposed Lafoea dumosa obliqua as a valid species of Toichopoma obliqua of the Lafoeidae family. Minimal differences in distinguishing characters (including coppinia structure) allow modern taxonomists to consider T. obliqua as synonym of Lafoea dumosa (Naumov, 1960, 1969; Cornelius, 1995; Schuchert, 2001). Our opinion is that obliqua should be considered as a morphological variation of dumosa, typical for cold waters.

For Kongsfjorden L. dumosa was mentioned by Lippert et al. (2001) as Lafoea fruticosa M. Sars, 1851 in samples from red algae Ptilota gunnery. According to Schuchert's (2001) opinion, supported by us, L. fruticosa, as well as several other Lafoea species, such as dumosa, gracillima, pocillum, grandis and others, must be considered as synonyms.

Our samples present the first record of the subspecies $L$. dumosa obliqua for Kongsfjorden. Colonies of the Arctic subspecies L. dumosa obliqua were found on different organic and inorganic substrata in coldwater areas of the Barents and Kara Seas, Recherché Bay in Svalbard, and West and East Greenland coasts at depth $0-200 \mathrm{~m}$, salinity about 32\%o and temperature near $2^{\circ} \mathrm{C}$.

Lafoea dumosa (together with Orthopyxis integra) is the most widely distributed hydroid species in Kongsfjorden. The species was found in 16 samples from all transects except for innermost part (OSSI) close to the tidal glacier. The majority of records ( 9 of 16 ) were from the middle-fjord transect HANS. The species was found at all depths within the sampling range, except at the shallowmost depth of $\mathrm{o}$.

The distribution by depth was about equal. The colonies were of different size (from $0.02 \mathrm{~g}$ to $0.5 \mathrm{~g}$ ) and resided mostly on bedrock - but sometimes gravel-substratum habitats at different environmental conditions, from sheltered to very exposed for wave impact, with or without some silt on the surface, and at variable currents. In most cases, L. dumosa was part of well-developed species-rich communities (56109 species) with high biomass and abundance of non-colonial species. Eleven samples of the 16 with colonies of $L$. dumosa were characterized by the dominance of barnacles Balanus balanus, and almost without kelp. Other group of habitats with $L$. dumosa was characterized by the presence of welldeveloped kelp assemblages with branched bryozoans as the dominant zoobenthic group. Two records of the Arctic subspecies L. dumosa obliqua were from the bottom of transect HANS, at $25 \mathrm{~m}$ and $30 \mathrm{~m}$ depth, influenced by lower temperatures.

Interestingly, the two most often recorded species, $L$. dumosa and O. integra, appear to be antagonists at sampling locations. They were found in 16 samples each but were recorded together in only 3 samples. Lafoea dumosa evidently prefers to inhabit deeper localities within Balanus balanus communities, whereas $O$. integra prefers shallower habitats and is more indifferent to the community type. Only five samples with L. dumosa were collected within well-developed kelp beds in opposite to 13 in the case of O. integra. The detached position of $L$. dumosa in relation to other abundant hydroid species is illustrated by Figure 6a. Among abundant species, L. dumosa was most positively related to depth and to related features, such as presence of some silt on the substratum surface or decrease in currents and wave exposure. Despite its relatively wide distribution in Kongsfjorden, $L$. dumosa could not be placed to the group of ecosystem's dominant or subdominant species.

\section{Family SERTULARIIDAE}

(19) Sertularella rugosa (Linnaeus, 1758)

Widespread Boreal-Arctic species, inhabiting depths from the littoral to $260 \mathrm{~m}$ (usually 25-50 m) and often associated with bryozoan Flustra sp. (but also with other substrata). For Kongsfjorden, it was mentioned by Lippert et al. (2001) in samples from kelp Laminaria digitata. In our samples the species was found from transects MITR and HANS in outer and middle parts of the fjord. Records were from four samples at shallow depths $1.3-10 \mathrm{~m}$. The habitats were 
bedrock overgrown by kelp, strongly exposed to waves and currents and without silt on the surface. Colonies of $S$. rugosa $(0.1-0.5 \mathrm{~g})$ were a part of a different kind of species-poor or moderately species-rich zoobenthic communities (32-74 species). The communities were characterized by small to large biomass $(76.2-1878.4 \mathrm{~g})$ with dominance of branched bryozoans or barnacles or without definite dominant species.

(20) Symplectoscyphus tricuspidatus var. acuminatus (Kirchenpauer, 1884)

This species was mentioned for Kongsfjorden by Ronowicz (2007) as Symplectoscyphus tricuspidatus (Alder, 1856). Our samples contain a coldwater, High-boreal-Arctic variety of bipolar species. In our opinion, the variety has several important characters: short corrugated internodes, short hydrothecae with curved abcauline walls and with longer adcauline marginal tooth and wrinkled gonothecae. According to Linko's (1912) opinion, the variety is geographically distinct and inhabits high-Arctic areas. Kudelin (1914) mentioned these hydroids as a subspecies of $S$. tricuspidatus. Additional investigations (for example, DNA analyses) are necessary to define its status as a valid species, subspecies or morphological variety.

These hydroids, which inhabit the upper sublittoral down to about $100 \mathrm{~m}$, were found in eight samples from transects MITR, GUIS and HANS, from outer and middle part of the fjord, within shallow depths of $1.3-5 \mathrm{~m}$. The species could be attributed to the group of species with high importance for zoobenthic communities. On transect MITR at $2.5 \mathrm{~m}$ depth, the biomass of this species reached $480 \mathrm{~g} \mathrm{~m}^{-2}$. This is a dominant species which defines the structure and composition of the community, occupying substratum and serving as an asylum for other benthic organisms. Based on this dominance, the special 'Symplectoscyphus community' type was described. This is a relatively poor community in the sense of species diversity (29 species) with intermediate abundance/biomass characteristics (total abundance of noncolonial organisms was 5100 ind. $\mathrm{m}^{-2}$; total biomass of zoobenthos was $553.6 \mathrm{~g} \mathrm{~m}^{-2}$ ). Elsewhere (7 samples), the biomass of Symplectoscyphus colonies was $<4 \mathrm{gm}^{-2}$ and this species was not dominant or subdominant. Such colonies were recorded from samples overgrown by kelp with dominance of branched bryozoans Eucratea loricata and Tricellaria ternata. All samples with Symplectoscyphus were from bedrock as the main substratum and without any silt on the surface because of very strong waves and currents.
Family HALECIIDAE

(21) Halecium labrosum Alder, 1859

Low-boreal-Arctic species, occurring from littoral zone to $470 \mathrm{~m}$ depth, at salinities of about $31-32 \%$ and a temperature range of $0-2^{\circ} \mathrm{C}$. In Kongsfjorden it was present in the middle and outer parts of the fjord, on transects MITR and HANS at a depth-range of $1.3-30 \mathrm{~m}$. Small colonies (0.01-0.2 g) were found in eight samples within bedrock or gravel habitats in a great variety of communities and environmental conditions. Colonies of Halecium labrosum could be a part of kelp-less, species-rich communities with dominance of barnacles $B$. balanus, or bivalve molluscs. They also inhabited impoverished species-poor zoobenthic communities without definite dominant species. In four samples of the eight where they were present, Halecium labrosum was found in a moderately speciesrich (60-75 species), branched bryozoans community within the kelp belt. The habitats were from sheltered to those very exposed to wave impact, affected by currents and mainly without silt on the surface of background substratum.

\section{(22) Halecium tenellum Hincks, 1861}

Bipolar species, inhabiting different organic and inorganic substrata at depths from littoral to $700 \mathrm{~m}$, occurred at salinity from $31 \%$ to $>34 \%$ and temperature from o to $3{ }^{\circ} \mathrm{C}$. It was found in only one sample from Kongsfjorden, from transect MITR in the outer part of the fjord, at $2.5 \mathrm{~m}$ depth. The habitat was bedrock with some kelp, very exposed to waves, with strong currents and no silt. The colony ( $0.2 \mathrm{~g}$ ) was part of a low-biomass $\left(76.2 \mathrm{~g} \mathrm{~m}^{-2}\right)$, moderately species-rich (40 species) zoobenthic community without definite dominant species.

\section{(23) Halecium halecinum (Linnaeus, 1758)}

Widespread Boreal-Arctic species found typically from depth $40-300 \mathrm{~m}$ depth (may range from 24 down to $1300 \mathrm{~m}$ ). It was only found in the middle part of Kongsfjorden, on transect HANS at $30 \mathrm{~m}$ depth. The habitat was bedrock without kelp, sheltered but with some currents. The colony (o.1 g) was part of a species-rich (95 species) B. balanus zoobenthic community with high biomass $\left(1317.2 \mathrm{~g} \mathrm{~m}^{-2}\right)$.

Two very small fragments of young colonies, Halecium sp. juv., were collected on transects GUIS at $2.5 \mathrm{~m}$ depth and HANS at $25 \mathrm{~m}$ depth. It was impossible to identify them to species level because fragments did not allow determination of branching type and hydrotheca construction. 